\title{
Empirical Measure of Wealth Effects in Household Consumption: The Case of Congo
}

\author{
Idrys Fransmel OKOMBI
}

Correspondence: Idrys Fransmel OKOMBI, Assistant at the Faculty of Economics Sciences, Marien NGOUABI University, Congo-Brazzaville. BP 69, Marien NGOUABI University, Faculty of Economis Sciences

\author{
Received: July 10, $2018 \quad$ Accepted: August 6, $2018 \quad$ Available online: August 16, 2018 \\ doi:10.11114/aef.v5i5.3542 URL: https://doi.org/10.11114/aef.v5i5.3542
}

\begin{abstract}
The purpose of this article is to determine the impact of wealth in household consumption, by focusing on wealth under monetary form. In this way, the correction error model ARDL type is used. The outcome estimations show a significant existence of wealth effect on a period 1991.Q1-2016.Q1. In this way, the marginal propensity to consume wealth equals 0,476 to a short term. However, this marginal propensity to consume wealth, though being significant and positive is down to the marginal propensities to consume income available in the long term that are up to 0,695 and 0,777 as regard the short and long term. Nevertheless, to improve the households' consumption level, the Congolese government can boost the monetary wealth by decreasing prices. More specifically, the government needs to lower value added tax (VAT).
\end{abstract}

Keywords: wealth effect, household consumption, ARDL, Congo

Codes Jel: E21, C32, 005

\section{Introduction}

The debate on household consumption and their economic implications is undoubtedly one of the most important themes of macro-economy that has gotten the attention of the economists, since the 1930s. This debate regained importance due to the financial crisis of 2008 , which lowered the household consumption in many developed countries. Basing on rhetorical approaches, many differences might explain the variation in consumption. In fact, component of the global demand, consumption is a stable function of the available income (Keynes, 1936). By proceeding to a critical analysis of the Keynes theory linking household's expenses to their daily income only, Friedman (1957) on the one hand, Ando and Modigliani (1963) on the other hand, proposed two simultaneous analysis frameworks to account that households are not narrow minded. They believe that households look to the future and plan their long term consumption instead. So the key to explain the consumption of the economic agents is no longer daily revenue. It is replaced according the Chicago economist by a permanent revenue, global resources, revenue (present and future) and estate to the theorists of life cycle. So by taking into account the anticipated daily and future revenues or the estate grouped under the theme Wealth in the consumption equation, we can not only value the marginal propensity of households to consume the daily revenue, but also a marginal propensity to consume their wealth.

Several empirical works tend to implement a positive correlation between consumption and estate (Guiso, Paiella and Visco, 2006; Pailla, 2007; Sierminska and Takhtamanova, 2007), weather on aggregated or individual data. However, the extent of this correlation is subject to vary depending on several factors, the composition of wealth (estate and financial); anticipation of prices evolution of financial assets (Cooper and Dynan, 2014). Since the financial market ${ }^{1}$ is not developed in the Monetary and Economic Community of Central Africa (MECCA) zone yet, the analysis of wealth effect in this article is centered on the effect described by Pigou (1947). In fact, when the price level increases, the actual savings are valued, households seek to restore the actual value of their estate by decreasing consumption for the benefit of saving. Pigou effect is theoretically valid for any form of wealth expressed in nominal terms (which is not index on prices evolution). Nonetheless, since the liquid component of wealth is the one that especially affects consumption, it is legitimate to specifically worry about the effect of actual savings. In other words, our article is only focused on the monetary part of wealth, and also appreciates its effect on household consumption.

\footnotetext{
${ }^{1}$ Central Africa stock estate.
} 
Taking Congo as base, poor country, member of the MECCA, the consumption function analysis seems convenient for at least two reasons. First, households' consumption is an important data for the well-being of the economy since it increases the demand of local products and can by a multiplier effect increase GDP and employment as well. Second, households' consumption function is part the instruments that allows to quantify the bell-being of the households. Up to now, household consumption expense is part of the privileged tools that some money lenders (World Bank) and economists use to measure poverty ${ }^{2}$. In this regard, it appears to be important for our article to highlight the determinants of household consumption, in order to account the necessary targets to improve the well-being of households in Congo. In view of the fact that monetary wealth is grasped to give impetus to household consumption (Patinkin, 1965) on prices stability ${ }^{3}$, a careful thinking on the support policies of household consumption can with other considerations (available income, actual interest rate, unemployment and public consumption) integrate the monetary part of wealth. This article joins policies aiming to boost the economy in order to fight unemployment, in a context of prices stability. Therefore, the analysis of actual wealth effect in the function of global demand enlightens the fact that a drop in prices is important enough to boost consumption by making households wealthier. This approach suggests that, full employment maybe achieved by a sufficient general drop in prices, which exercises a positive wealth effect on global demand to augment the actual wealth of households. In this way, the determinants of household consumption in the Congo, raises the question of wealth effect of household consumption. The purpose of our article is to measure the wealth effect of household consumption. Following the introduction, our article is organized around three main parts. Thus, the second part of our work is devoted to the review of the literature on wealth effects in the household consumption function. The second concerns the methodology of the study. The third is devoted to the conclusion.

\section{Literature Review}

The wealth effect in the function of household consumption has its theoretical foundations in the theory of permanent revenue or in the hypothesis of life cycle (Friedman, 1957; Ando and Modigliani, 1963). According to these authors, daily revenue, anticipated future revenues, or the estate, that are coupled under the generic theme of Wealth, make up an important determinant of Consumption. Ando and Modigliani (1963) have a household consumption function which the marginal propensity to consume wealth is around 0, 06 in the USA. Houizolt et al. (2000) explain the US household consumption dynamism in the 1990s by a high increase in the stock rate in that period, and values a propensity to consume wealth to 0, 05, very close to the one found in the works of Ando and Modigliani (1963).

Many works have devoted their analysis on the effect of financial and estate patrimony on household consumption (Guiso et al., 2006; Pailla, 2007; Sierminska and Takhtamanova, 2007). The results of these works enlighten the different reaction of consumption, which the sense and the extent depend on the nature of assets (financial or estate). Nonetheless, the marginal propensities to consume wealth are all positive, but with different proportions. So, the marginal propensities to consume the total wealth in Italy during 1991-2002, financial and estate are respectively 0,02 ; 0,02 and 0, 04 (Guiso et al., 2006). However, the propensities to consume the total wealth, financial and estate in Italy from 1991-2002 are 0, 04; 0, 02 and 0, 09 (Paiella, 2007).

After the outburst of the financial crisis of 2008, several works have focused their attention on price index of estate assets (Gortz, and Petersen, 2013; Campbell and Cocco, 2007; Disney Gathergood and Henley, 2010). The results of these works show consumption elasticities in relation to estate price in Denmark are respectively 0, 08 in 1987-1996 (Gortz, and Petersen, 2013); 1, 2 from 1988-2000 in Great Britain (Campbell and Cocco, 2007) ; 0,3 from 1994-2003 in Great Britain (Disney et al., 2010).

By resorting to a panel of 5 developed countries ${ }^{4}$, gross financial wealth effect is significant in all countries (Antonin, Plane and Sampognaro, 2017), except Germany. So, in this study, authors point out that wealth effect is high in Spain where there's been a financial and estate bubble outburst in 2007, coupled with consumption elasticity of gross financial wealth of 0,19 , followed by the US, where the financial market is more developed than in Continental Europe $(0,14$ of elasticity), finally Great Britain and France display similar effects ( 0,09 of elasticity).

As regard literature review, it appears that wealth effect has not been an object of investigation in Africa yet. Nevertheless, a study on micro economical determinants in Ghana from a correction error model show that household consumption depends on available revenue (Bonsu and Muzindutsi, 2017). The long term relation of household consumption's function reveal that the marginal propensity to consume in Ghana is around 0, 797. Furthermore, the analysis of the impulsive response and the variance break down have in short term show that, household consumption is

\footnotetext{
${ }^{2}$ The major implication of this monetary measure of utility of household has been the focus of most of the institutions equipped to fight poverty on policies aiming to increase household income.

${ }^{3}$ Weak prices level, predictable and stable.

${ }^{4}$ Germany, France, Spain, Great Britain and the US.
} 
only affected by prices level variations. However, an important limit that can be noticed from this article is its incapacity to account the effect of prices level on actual savings.

\section{Study Methodology}

\subsection{Theoretical Framework}

In the life cycle theory, (Modigliani and Brumberg, 1954), estate accumulation allows to delay household purchasing power in time (delay consumption), therefore smoothing out in whole period of their existence. The basic version of this model supposes an absolutely certain and perfect world, a unique estate asset. In this framework, the marginal propensity to consume wealth is a simple function of lifetime (T), of interest rate (r), preference for the present $(\delta)$ and the function parameter of utility translating consumption preferences (u). So basing on Masson analysis (1988), the current consumption function of an individual age $\mathrm{a}$ is as the following:

$$
\mathrm{Ca}=\mathrm{k}(\mathrm{r}, \mathrm{T}-\mathrm{a}, \delta, \mathrm{u})[\mathrm{Ea}+\mathrm{Wa}]
$$

Wa means estate level possessed at age a, Ea the value of one's human capital corresponding to the updated sum (to age a) of one's work revenue, present and future. The current consumption is proportional to the total wealth of the individual, human or nonhuman, proportionality translating the fact that savings is not a luxury.

To illustrate their model, Modigliani and Brumberg (1954) take a very simple case where household consume all of it lifetime revenue (considered stable until retirement), with $\mathrm{r}=\delta=0$ and one logarithm utility function. Consumption is then stable in time, equal to permanent revenue, simple temporal average of revenues. To age a, the consumption amount is written as the following:

$$
\mathrm{Ca}=1 /(\mathrm{T}-\mathrm{a})[\mathrm{Ea}+\mathrm{Wa}]
$$

In this very simple case, the propensity to consume wealth (or wealth effect) simply corresponds to the inverse of household decision. Theoretically, every anticipated change of assets value is already integrated in the consumption behaviors. However, a non-anticipated choc modifying the wealth value will have consequences on the consumption behaviors, function of the $\mathrm{k}$ value. The extent of this effect will still depend on the nature of the choc, little lasting or permanent: little lasting variations of prices will have less impact on household expenses.

As mentioned above, household wealth influences household consumption.

Nevertheless, it is important to underline that households are wealthier when they possess financial assets, estates and monetary wealth. In view of the fact that monetary market remains a unique backbone of capital market, developed in the MECCA zone, only the monetary part of wealth attracts our attention. Since then, the functional form of household consumption takes the following form:

$$
\text { CONS }=f(R I C H)
$$

where RICH, represents wealth.

By increasing the consumption function of the other control variables, such as income available of the households (YDM), real interest rate (TIR), public consumption (CPUB) and unemployment rate (CHO), the model then takes the form next:

$$
\text { CONS }=f(R I C H, Y D M, T I R, C P U B, C H O)
$$

By linearizing relation 4 , and taking into account the time factor in the dynamics of household consumption, we obtain the following formalization:

$$
\mathrm{CONS}_{t}=\beta_{1} \mathrm{RICH}_{t}+\beta_{2} \mathrm{YDM}_{t}+\beta_{3} \mathrm{TIR}_{t}+\beta_{4} \mathrm{CPUB}_{t}+\beta_{5} \mathrm{CHO}_{t}+\mu_{t}
$$

By introducing logarithm $(\mathrm{L})$ to certain variables of equation 5 , we get the following equation:

$$
\text { LCONS }_{t}=\beta_{1} L_{R I C H}+\beta_{2} L Y D M_{t}+\beta_{3} \text { TIR }_{t}+\beta_{4} L C P U B_{t}+\beta_{5} \text { CHO }_{t}+\mu_{t}
$$

LCONS, LYDM and LCPUB respectively represent logarithms of the household consumption, logarithm of available household revenue and logarithm of public consumption.

\subsection{Data Sources}

The data sources used are of secondary model and are relatives to the period 1991-2016, or 26 observations. They were in great compiled on the official website of the World Bank (WID, 2016) and of the IMF. It's all about household consumption variables, public consumption, actual interest rates, unemployment, money offer, general prices level, primary income, tax on revenue. The monetary wealth results from the difference between currency offer and general prices level. As for available revenue, it is deducted from the difference between primary revenue and tax on revenue, in view of the less structured character of the Congolese economy coupled with insufficient data on social dues, services 
and other relocations received. Furthermore, it should be noted first, except from the interest and unemployment rate that all these variables are expressed in local currency unit. Second, the annual data have been transform into quarterly data (1991.Q1-2016.Q1). In this regard, the quarterly method of annual data collected (Denton, 1971), mostly used by IMF's economists has been adopted. In fact, it is important to admit that econometrics rests on a certain number of relatively binding conditions for the adoption of the estimation results. It is especially the case with the length of series that is sometimes handicapped in developing countries. Finally, logarithm is introduced in adopted variables, except the interest and unemployment rate, expressed in percentages.

\subsection{Analysis Method}

\subsubsection{Description of Variables Used}

Household consumption as a measure of standard of living of the population, was done through its evolution in local currency unit. The explanatory variables of the model is respectively wealth, available revenue, actual interest rate, unemployment and public consumption. The first variable allows to take wealth into account in the function of consumption. It's about Pigou (1947) effect: when the prices level increases, the actual savings are valued and, household seek to set up the actual value of their patrimony by deducting consumption for the benefit of savings. Wealth has therefore a positive effect on consumption. This variable is approximate to the difference in currency offer and general prices level. The second variable is adopted, in order to realize the Keynes psychological law. When the available revenue of household rises, so is consumption. The available revenue effect on household consumption is positive. The third explanatory fluctuation regards the actual interest rate evolution. The interest rate allows household to engage in arbitrage consumption and savings. The effect of actual interest rate in household consumption is differentiated. In the other hand, higher actual interest rate leads to a consumption renunciation and increases savings for households. This substitution effect tends to decrease household consumption. Even so, higher interest rates generate a revenue effect that might lead to a higher consumption: household can increase their everyday consumption. In the literature, an interest rate effect on savings' interest in ambiguous. The fourth fluctuation, realize the reaction of household to economic policy. Basing on Keynesian theory, a public consumption augmentation by multiplying effect, leads to GDP augmentation, which in turn, is translated by an increase in revenue under the forms of profit and wages. This income growth is inescapably translated by an augmentation in consumption. As for unemployment, it is taken into account in order to explain the behavior of household savings. The higher the unemployment rate, the higher the probability of the individuals to be unemployed rises and, conditionally to everyday revenue, increases the revenue variance to the individual level. So, an unemployment augmentation in translated by a decrease of household consumption.

\subsubsection{Econometrics Data Analysis}

Before estimating short and long term coefficients, we are going to determine the order of fluctuation integrations.

\subsubsection{Test of Stationary Variables}

In this case, we use the Dickey and Fuller (1981) test, performed on explained variables and the four explanatory selected variables have provided the results mentioned in the following table:

Table 1. Integration order of variables

Source: from Eviews author

\begin{tabular}{l|l|l|l|l|l}
\hline Variable & LCONS & YDM & TIR & CPUB & CHO \\
\hline Integration order & $\mathrm{I}(1)$ & $\mathrm{I}(1)$ & $\mathrm{I}(1)$ & $\mathrm{I}(1)$ & $\mathrm{I}(0)$ \\
\hline
\end{tabular}

An interesting fact springs from these tests of root unit: explained variable (LCons) is I(1) whereas the explanatory variables are weather I(1) or I(1). So, the application ARDL model is suitable for this article. Before the application of this type, we should first determine the optimal Lag.

\subsubsection{Number of Optimal Delays}

An important step in terms of dynamic types is the determination of the number of optimum delays. To do this, different criteria are often used: Akaike Information Criterion (AIC) and Schwartz Information Criterion (SIC). If applicable, the test (see appendix) indicates a delay in LR, FPE, AIC, and SC criterion. So, the number of $\mathrm{N}^{\circ} 1$ delay is opted.

\subsubsection{Estimation of ARDL Model}

To examine relations between consumption (Lcons) and explanatory variables, study resorts to co-integration approach based on auto-regressive delay types (ARDL: Auto-Regressive Distributed Lag) developed by Pesaran and Shin (1995, 1999), Pasaran, Shin and Smith (1996), and Pasaran (1997). In fact, traditional co-integration approaches ( Engle and Granger, 1987; Johansen (1988) to determine the existence of a long term relation between variables present serious bounds: necessary to have integrated series of the same order $\mathrm{I}(0)$ or $\mathrm{I}(1)$ and lack power towards small sized samples. 
The co-integration approach proposed by Pesaran, Shin and Smith and based on ARDL type, allows to mitigate the bounds. This approach allows to test the long term relation between variables $\mathrm{I}(0)$ and $\mathrm{I}(1)$ and provides strong estimations short and long term relations for small sized samples placed under 80 observations (Narayan, 2005). That's ARDL specification is written as the following.

$\Delta L \operatorname{CONS}_{t}=\alpha_{0}+\sum_{i=1}^{P} \alpha_{1 i} \Delta L \operatorname{CONS}_{t-i}+\sum_{i=0}^{q} \alpha_{2 i} \Delta L R I C H_{t-i}+\sum_{i=0}^{q} \alpha_{3 i} \Delta L Y D M_{t-i}+\sum_{i=0}^{q} \alpha_{4 i} \Delta T I R_{t-i}+\sum_{i=0}^{q} \alpha_{5 i} \Delta L C P U B_{t-i}+$ $\sum_{i=0}^{q} \alpha_{6 i} \Delta$ CHO $_{t-1}+\beta_{1}$ LCONS $_{t-1}+\beta_{2}$ LRICH $_{t-1}+\beta_{3} L Y D M_{t-1}+\beta_{4} T I R_{t-1}+\beta_{5} L C P U B_{t-1}+\beta_{6} C_{H-1}+\varepsilon_{t}$

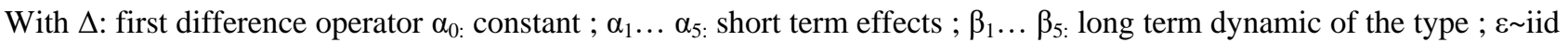
$(0, \sigma)$ : error term (white noise).

In terms of ARDL method application, it is suitable to note $\operatorname{ARDL}(p, q)$ that will be the base for the bounds' test which, in turn will confirm or refute presence of co-integration relation or the long term. Focusing on delays selection criteria, ARDL type has been estimated with a maximum 1 delay for all variables. Table 2 shows that all coefficients of ARDL type $(1,1)$ are significant (Prob $<5 \%$ and even $1 \%$ in the majority of cases). The type is globally significant, Prob (F-statistic) $=0.00)$. R-square of 0,994 shows that $99,4 \%$ of checking account's balance variations are explained by the fluctuations of significant variables of the type. Except public consumption, all variables are significant.

Table 2. Outcomes of ARDL(1,1)

\begin{tabular}{c|c|c|c}
\hline \multicolumn{5}{c}{ Independent variables: LCONS } \\
\hline Variable & Coefficient & t-Statistic & Prob. $^{*}$ \\
\hline LCONS(-1) & 0.690475 & 6.021031 & 0.0000 \\
\hline LRICH & 0.458659 & 3.862657 & 0.0014 \\
\hline LRICH(-1) & -0.795493 & -4.451130 & 0.0004 \\
\hline LYDM & 0.580890 & 2.497158 & 0.0238 \\
\hline TIR & -0.003711 & -2.103817 & 0.0516 \\
\hline LCPUB & 0.021018 & 1.533372 & 0.1447 \\
\hline LCPUB(-1) & 0.027630 & 2.104855 & 0.0515 \\
\hline CHO & -0.147979 & -3.222084 & 0.0053 \\
\hline C & -1.475102 & -0.798151 & 0.4365 \\
\hline \multicolumn{5}{c}{ R-squared: 0.994342} \\
\hline F-statistic & 351.5001 & Durbin-Watson stat & 1.819727 \\
\hline Prob(F-statistic) & 0.000000 &
\end{tabular}

Source: author from Eviews

\subsubsection{Cointegration Test of Variables}

The primary objective of this test is to enlighten on whether there is a long term co-relationship of variables.

For this purpose, the cointegration test of Pesaran, Shin and Smith. (2001) requires that the ARDL model be estimated in advance. The calculated test statistic, Fisher's F value, will be compared to the critical values (which form bounds) as follows:

if Fisher> upper bound: Cointegration exists;

if fisher is <lower bound: Cointegration does not exist;

if the lower bound is <Fisher <upper bound: No conclusion.

Thus, the results of Table 3 show that the value of $F=8.182$ highly exceeds those of superior bounds of critical values (even at 1\%). For this purpose, zero hypothesis is rejected from the absence of long term relation and concluded to a long term relation between variables.

Table 3. Outcomes of the cointegration test of Pesaran et al. (2001)

\begin{tabular}{l|l|l|l}
\hline Variables & LCONS LRICH LYDM TIR LCPUB CHO \\
\hline Critical threshold & Bound < & Bound $>$ & \\
\hline $10 \%$ & 2.08 & 3 & \multirow{3}{*}{ Calculated F-stat: } \\
\hline $5 \%$ & 2.39 & 3.38 & 8.182099 \\
\hline $2.5 \%$ & 2.7 & 3.73 & \\
\hline $1 \%$ & 3.06 & 4.15 & \\
\hline
\end{tabular}

Source: author from Eviews

\subsubsection{Long Term Coefficients and Short Term Dynamic}

The outcomes of long and short term are represented in table 4 . 
Table 4. Outcomes' estimation of long and short term coefficients

\begin{tabular}{c|c|c|c}
\hline \multicolumn{4}{c}{ Dependent variable: $\Delta \boldsymbol{L C O N S}$} \\
\hline Variable & Coefficient & t-Statistic & Prob. \\
\hline$\Delta$ LRICH & 0.476401 & 4.846223 & 0.0002 \\
\hline$\Delta$ LYDM & 0.694774 & 2.104499 & 0.0515 \\
\hline$\Delta$ TIR & -0.004063 & -1.358572 & 0.1931 \\
\hline$\Delta$ LCPUB & 0.020726 & 2.380264 & 0.0301 \\
\hline$\Delta$ CHO & -0.179650 & -3.383992 & 0.0038 \\
\hline CointEq(-1) & -0.288124 & -5.575597 & 0.0000 \\
\hline \multicolumn{4}{|c|}{ Dependent variable: LCONS } \\
\hline Variable & Coefficient & t-Statistic & Prob. \\
\hline LRICH & 0.393591 & 0.705249 & 0.4908 \\
\hline LYDM & 0.776712 & 1.923128 & 0.0724 \\
\hline TIR & -0.011990 & -2.274406 & 0.0371 \\
\hline LCPUB & 0.157169 & 2.067032 & 0.0553 \\
\hline CHO & -0.478085 & -7.804414 & 0.0000 \\
\hline C & -4.765693 & -0.751772 & 0.4631 \\
\hline
\end{tabular}

Source: author from Eviews

The outcomes of test bounds have shown that there exist a long term relationship between the two variables and which is confirmed by a correction error type. In fact, there is, as planned, an adjustment coefficient that is negative (-0, 29), between 0 and -1 and highly significant (probability=0. 00).

The outcomes of estimations are of good quality. Indeed, diagnosis tests in terms errors (see appendix) show that probability linked to Jarque Bara statistics is equal to 0, 393 higher to 5\%, hypothesis of normality of variables is accepted. In other words, there is a 39, 3\% chance to make a bad decision. The Breusch-Godfrey test allows us to accept the null hypothesis of no autocorrelation of residues. otherwise, a chart of the functions of autocorrelation and autocorrelation partial of the residues up to 12 delays. So, a total absence of autocorrelation of the residues is observed. In fact, whether in the case of simple or partial autocorrelation of the residuals, all the terms are within the confidence interval (the limits which represent the threshold at which the autocorrelation is considered as significant). Such an observation is confirmed by the Ljung-Box test whose probability of the Q statistic is well above the threshold of 5\% and even $10 \%$ (the null hypothesis of the absence of autocorrelation of the residues is therefore accepted). Moreover, the $\mathrm{ARCH}$ test shows that the probability of « Obs*R-squared » equals 0,7732 , superior to 5\%, zero hypothesis of homoscedasticity of remainders is accepted. The test of White allows us to accept the homoscedasticity hypothesis of errors, for the y relative equals 0, 2463, superior to 5\%; Breusch-Pagan-Godfrey test reveal that there is no co-relation of errors.

Finally, the stability tests of type, Cusum and Cusum squared show that the model is structurally and punctually stable.

Furthermore, it is important to underline that the hypothesis of our research is verified. Indeed, a growth of monetary wealth of 1 point is translated by an augmentation of household consumption of 0,476 point in short term, and wealth effect on household consumption is not significant in long term. Nonetheless, the short term outcome implies that when the prices level decreases, the actual savings are valued, which increases household consumption. The marginal propensity to consume also has the expected sign whether in long or short term. In fact, an augmentation of the available revenue of point 1 leads to a consumption augmentation of 0,695 point in short term consumption and of 0 , 777 point. These outcomes suggest that to improve the standard of living of the population, the Government can lower taxes on household income. Interest rate has a negative impact but, not significant on short term consumption. However, in long term, an interest rate growth of 1 point induces a consumption decrease of 0,012 point. Public consumption also has the expected sign. For this purpose, a public consumption increase of 1 point leads to a consumption growth of 0 , 021 point in short term and 0,157 in long term. So, the government can increase public spending, which by multiplying effect, GDP growth and, hence household revenue under wage form. Unemployment coefficient also has the expected sign. In fact, unemployment increase of 1 point is translated by a consumption decrease of 0,179 point in short term and of 0, 478 in long term. Such an outcome implies that a fall in unemployment reduces uncertainty and, hence savings precaution of households (household consumption increases).

\section{Conclusion}

The purpose of our article was to evaluate monetary wealth effects of household consumption. To this end, the error correction model ARDL has been used. The outcomes of our estimations have revealed that monetary wealth has a positive impact on household consumption. So, the marginal propensity to come wealth in short term is 0,695 . In long term, wealth has no effect household consumption; but the marginal propensity to consume income available equals 
0,777 . In relation to what mentioned before, the marginal propensity to consume monetary wealth is inferior to the marginal propensity to consume income available. However, to improve household consumption, the Congolese government can increase monetary wealth by decreasing general prices level. The government can specifically lower on added value tax (AVT).

\section{References}

Ando, A., \& Modigliani, F. (1963). The 'Life Cycle' Hypothesis of Saving: Aggregate Implications and Tests, The American Economic Review, 53(1).

Antonin, C., Plane, M., \& Sampognaro, R. (2017). les comportements de consommation des ménages ont-ils été affectés par la crise de 2008 ? une analyse économétrique de cinq grands pays développés, Revue de l'OFCE, 177-225. DOI 10.3917/reof.151.0177.

Bonsu, C. O., \& Muzindutsi, P. F. (2017). Macroeconomic Determinants of Household Consumption Expenditure in Ghana: A Multivariate Cointegration Approach, International Journal of Economics and Financial Issues, 7(4), 737-745.

Campbell, J. Y., \& Cocco, J. (2007). How do house prices affect consumption? Evidence from micro data, Journal of Monetary Economics, 54(3), 591-621. https://doi.org/10.1016/j.jmoneco.2005.10.016

Cooper, D., \& Dynan, K. (2014). Wealth effects and macroeconomic dynamics, Journal of Economic Surveys, à paraître.

Denton, F. T. (1971). Adjustment of monthly or Quarterly Series to Annual Totals: An Approach based on Quadratic Minimization. Journal of the American Statistical Association, 66(333), 99-102. https://doi.org/10.1080/01621459.1971.10482227

Dickey, D. A., \& Fuller, W. A. (1981). Likelihood ratio statistics for autoregressive time series with a unitroot, Econometrica, 49(4), 1057-1072. https://doi.org/10.2307/1912517

Disney, R., Gathergood, J., \& Henley, A. (2010). House Price Shocks, Negative Equity, and Household Consumption in the United Kingdom, Journal of the European Economic Association, 8(6), 1179-1207. https://doi.org/10.1162/jeea_a_00022

Engle, R. F., \& Granger, C. W. (1987). Co-integration and error correction: Representation, estimation, and testing, Econometrica, 55(2), 251-276. https://doi.org/10.2307/1913236

Friedman, M. (1957). A Theory of the Consumption Function, Princeton University Press.

Gortz, B. M., \& Leth-Petersen, S. (2013). Housing wealth and consumption: a micro panel study, Economic Journal, 123, 401-428. https://doi.org/10.1111/ecoj.12017

Guiso, L., Paiella, M., \& Visco, I. (2006). Do capital gains affect consumption? Estimates of wealth effects from Italian household behavior, dans L. Klein (éd.), Long Run Growth and Short Run Stabilization: Essays in Memory of Albert Ando (1929-2002), Edward Elgar, Cheltenham.

Houizot, C., et al. (2000). Plus-values, consommation et épargne: Une estimation de l'effet richesse aux États-Unis et au Royaume-Uni, Revue de l'OFCE, $\mathrm{n}^{\circ} 73$, avril.

Johansen, S. (1988). Statistical analysis of cointegration vectors, Journal of Economic.

Keynes, J. M. (1936). The General Theory of Employment, Interest and Money, in The Collected Writings of John Maynard Keynes, Vol. VII, London, Macmillan, 1973.

Modigliani, F., \& Brumberg, R. (1954). Utility analysis and the consumption function: an interpretation of cross-section data, dans K. K. Kurihara, éd., Post-Keynesian Economics, NJ. Rutgers University Press, New Brunswick, 388-436.

Narayan, P. K. (2005). The saving and investment nexus for China: evidence from cointegration tests. Applied economics, 37(17), 1979-1990. https://doi.org/10.1080/00036840500278103

Paiella, M. (2007). Does wealth affect consumption? Evidence for Italy, Journal of Macroeconomics, 29, 189-205. https://doi.org/10.1016/j.jmacro.2005.06.001

Patinkin, D. (1965). Money, interest and prices - An integration of monetary and value theory, New York, Harper et Row publisher, 1965, trad. fr. La monnaie, l'intérêt et les prix - Une intégration de la théorie de la monnaie et de la théorie de la valeur, Paris, P.U.F., 1972.

Pesaran, H. M., \& Shin, Y. (1995). Autorgressive Distributed Lag Modelling Approach to Cointegration Analysis, DEA Working Paper Series $N^{\circ}$ 9514, Department of Applied Economics, University of Cambridge. 
Pesaran, H. M., \& Shin, Y. (1999). Autorgressive Distributed Lag Modelling Approach to Cointegration Analysis, Chapter, 11, in Storm, S. (ed), Econometrics and Econmic theory in the 20th Century: The Ragnar Frisch Centennial Symposium, Cambridge University Press. Cambridge. https://doi.org/10.1017/CCOL521633230.011

Pesaran, H. M., Shin, Y., \& Smith, R. (1996). Testing the Existence of a long-run relationship, DEA Working Paper Series $\mathrm{N}^{\circ}$ 9622, Department of Applied Economics, University of Cambridge.

Pesaran, M. H., \& Shin, Y. (1997). An autoregressive distributed lag modeling approach to cointegration analysis. England: University of Cambridge.

Pesaran, M. H., Shin Y., \& Smith, R. J. (2001). Bounds Testing Approaches to the Analysis of Level Relationships. Journal of Applied Econometrics, 16, 289-326. https://doi.org/10.1002/jae.616

Pigou, A. C. (1947). Economic Progress in a Stable Environment, Economica, 14, August, 180-88. https://doi.org/10.2307/2549787

Sierminska, E., \& Takhtamanova, Y. (2007). Wealth effects out of financial and housing wealth: cross country and age group comparisons. Federal Reserve Bank of San Francisco Working Paper, $\mathrm{n}^{\circ}$ 2007-01, Federal Reserve Bank of San Francisco. https://doi.org/10.2139/ssrn.1007825

\section{Appendix}

Appendix 1. Outcomes of stationary tests

\begin{tabular}{|c|c|c|c|c|}
\hline \multirow[b]{2}{*}{ Variables } & \multicolumn{3}{|c|}{ ADF Test } & \multirow[b]{2}{*}{$\begin{array}{l}\text { Integration } \\
\text { order }\end{array}$} \\
\hline & ADF statistics & $\begin{array}{l}\text { Statistics in } \\
\quad \text { first } \\
\text { differcencies }\end{array}$ & $\begin{array}{c}\text { Crical value of } \\
\text { Mckinon }\end{array}$ & \\
\hline LCONS & -1.959821 & -4.308754 & -2.892200 & $\mathrm{I}(1)$ \\
\hline LRICH & -0.672659 & -3.136849 & -2.892200 & $\mathrm{I}(1)$ \\
\hline LYDM & -2.373216 & -4.189705 & -2.890926 & $\mathrm{I}(1)$ \\
\hline TIR & -0.946398 & -3.492336 & -2.893589 & $\mathrm{I}(1)$ \\
\hline $\mathrm{CHO}$ & -2.979304 & - & -2.892200 & $\mathrm{I}(0)$ \\
\hline
\end{tabular}

Source: author from Eviews

Appendix 2. Determination of optimal Lag

VAR Lag Order Selection Criteria

Endogenous variables: LCONS LRICH LYDM TIR LCPUB CHO

Exogenous variables: $\mathrm{C}$

Date: 05/28/18 Time: 21:15

Sample: 1991Q1 2016Q4

Included observations: 25

\begin{tabular}{cccccc}
\hline \hline Lag & LogL & LR & FPE & AIC & SC \\
\hline \hline 0 & -51.21357 & NA & $3.92 \mathrm{e}-06$ & 4.577085 & 4.869616 \\
$\mathbf{1}$ & $\mathbf{1 3 1 . 3 6 7 2}$ & $\mathbf{2 6 2 . 9 1 6 3 *}$ & $\mathbf{3 . 4 7 e - 1 1 *}$ & $\mathbf{- 7 . 1 4 9 3 7 7 ^ { * }}$ & $\mathbf{- 5 . 1 0 1 6 6 6 *}^{*}$ \\
\hline \hline
\end{tabular}

* indicates lag order selected by the criterion

LR: sequential modified LR test statistic (each test at 5\% level)

FPE: Final prediction error

AIC: Akaike information criterion

SC: Schwarz information criterion

HQ: Hannan-Quinn information criterion

Source: author from Eviews 
Appendix 3. Estimation outcome ARDL model

Dependent Variable: LCONS

Method: ARDL

Date: 05/28/18 Time: $21: 17$

Sample (adjusted): 1991Q2 1997Q2

Included observations: 25 after adjustments

Maximum dependent lags: 1 (Automatic selection)

Model selection method: Akaike info criterion (AIC)

Dynamic regressors (1 lag, automatic): LRICH LYDM TIR LCPUB CHO

Fixed regressors: $\mathrm{C}$

Number of models evaluated: 32

Selected Model: ARDL(1, 1, 0, 0, 1, 0)

\begin{tabular}{crlrr}
\hline \hline & & & \\
Variable & Coefficient & Std. Error & t-Statistic & Prob. $^{*}$ \\
& & & & \\
\hline LCONS(-1) & 0.690475 & 0.114677 & 6.021031 & 0.0000 \\
LRICH & 0.458659 & 0.237484 & 3.862657 & 0.0014 \\
LRICH(-1) & -0.795493 & 0.178717 & -4.451130 & 0.0004 \\
LYDM & 0.580890 & 0.232620 & 2.497158 & 0.0238 \\
TIR & -0.003711 & 0.001764 & -2.103817 & 0.0516 \\
LCPUB & 0.021018 & 0.013707 & 1.533372 & 0.1447 \\
LCPUB(-1) & 0.027630 & 0.013127 & 2.104855 & 0.0515 \\
CHO & -0.147979 & 0.045927 & -3.222084 & 0.0053 \\
C & -1.475102 & 1.848149 & -0.798151 & 0.4365 \\
& & & & \\
\hline \hline & & & & \\
R-squared & 0.994342 & Mean dependent var & 5.884238 \\
Adjusted R-squared & 0.991513 & S.D. dependent var & 0.447523 \\
S.E. of regression & 0.041227 & Akaike info criterion & -3.265738 \\
Sum squared resid & 0.027195 & Schwarz criterion & -2.826942 \\
Log likelihood & 49.82172 & Hannan-Quinn criter. & -3.144034 \\
F-statistic & 351.5001 & Durbin-Watson stat & 1.819727 \\
Prob(F-statistic) & 0.000000 & & \\
& & & \\
\hline \hline
\end{tabular}

*Note: p-values and any subsequent tests do not account for model selection.

Source: author from Eviews

Appendix 4: Outcome Cointegration test of variables

ARDL Bounds Test

Date: 05/28/18 Time: 21:18

Sample: 1991Q2 1997Q2

Included observations: 25

Null Hypothesis: No long-run relationships exist

\begin{tabular}{lll}
\hline \hline Test Statistic & Value & $\mathrm{k}$ \\
\hline \hline F-statistic & 8.182099 & 5 \\
\hline \hline
\end{tabular}

Critical Value Bounds

\begin{tabular}{lcc}
\hline \hline Significance & I0 Bound & I1 Bound \\
\hline \hline $10 \%$ & 2.08 & 3 \\
$5 \%$ & 2.39 & 3.38 \\
$2.5 \%$ & 2.7 & 3.73 \\
$1 \%$ & 3.06 & 4.15 \\
\hline \hline
\end{tabular}

Source: author from Eviews 
Appendix 5. Short and long term outcomes of coefficients

ARDL Co integrating And Long Run Form

Dependent Variable: LCONS

Selected Model: ARDL(1, 1, 0, 0, 1, 0)

Date: 05/28/18 Time: 21:19

Sample: 1991Q1 2016Q4

Included observations: 25

Co integrating Form

\begin{tabular}{crrrr}
\hline \hline & & & & \\
Variable & Coefficient & Std. Error & t-Statistic & Prob. \\
& & & & \\
\hline \hline & & & & \\
D(LRICH) & 0.476401 & 0.196607 & 4.846223 & 0.0002 \\
D(LYDM) & 0.694774 & 0.330138 & 2.104499 & 0.0515 \\
D(TIR) & -0.004063 & 0.002991 & -1.358572 & 0.1931 \\
D(LCPUB) & 0.020726 & 0.008708 & 2.380264 & 0.0301 \\
D(CHO) & -0.179650 & 0.053088 & -3.383992 & 0.0038 \\
CointEq(-1) & -0.288124 & 0.051676 & -5.575597 & 0.0000 \\
& & & & \\
\hline \hline
\end{tabular}
0.1572

Cointeq $=$ LCONS $-(0.3936 *$ LRICH $+0.7767 *$ LYDM $-0.0120 *$ TIR + $*$ LCPUB $\quad-0.4781 *$ CHO $\quad-4.7657$ )

Long Run Coefficients

\begin{tabular}{crrrr}
\hline \hline Variable & Coefficient & Std. Error & t-Statistic & Prob. \\
& & & & \\
\hline \hline & & & & \\
LRICH & 0.393591 & 0.558089 & 0.705249 & 0.4908 \\
LYDM & 0.776712 & 0.975865 & 1.923128 & 0.0724 \\
TIR & -0.011990 & 0.005272 & -2.274406 & 0.0371 \\
LCPUB & 0.157169 & 0.076036 & 2.067032 & 0.0553 \\
CHO & -0.478085 & 0.061258 & -7.804414 & 0.0000 \\
C & -4.765693 & 6.339283 & -0.751772 & 0.4631 \\
& & & & \\
\hline \hline
\end{tabular}

Source: author from Eviews

Appendix 6. Robustness tests of the estimated ARDL model (1, 1, 0, 0, 1, 0)

\section{Normality test}

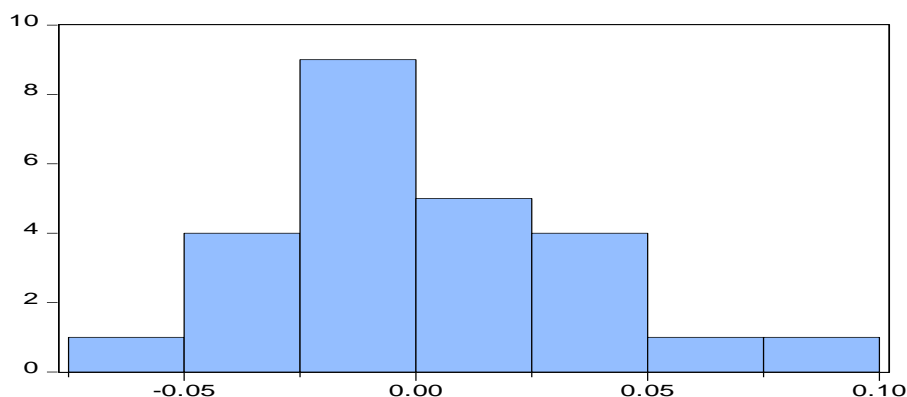

\begin{tabular}{lr|} 
Series: Residuals \\
Sample 199102 199702 \\
Observations 25 \\
Mean & $2.42 e-15$ \\
Median & -0.002193 \\
Maximum & 0.082834 \\
Minimum & -0.050929 \\
Std. Dev. & 0.033662 \\
Skewness & 0.667653 \\
Kurtosis & 2.903543 \\
Jarque-Bera & 1.867025 \\
Probability & 0.393170 \\
\hline
\end{tabular}




\section{Autocorrelation test}

Breusch-Godfrey Serial Correlation LM Test:

\begin{tabular}{llll}
\hline \hline F-statistic & 2.839832 & Prob. F(2,14) & 0.0922 \\
Obs*R-squared & $\mathbf{7 . 2 1 5 1 4 4}$ & Prob. Chi-Square(2) & $\mathbf{0 . 0 6 7 1}$ \\
\hline \hline
\end{tabular}

\section{Ljung-Box test}

Date: 07/26/18 Time: 12:08

Sample: 1991Q1 2016Q4

Included observations: 25

Q-statistic probabilities adjusted for 1 dynamic regressor

\begin{tabular}{|c|c|c|c|c|c|c|}
\hline Autocorrelation & Partial Correlation & & $\mathrm{AC}$ & $\mathrm{PAC}$ & Q-Stat & Prob* \\
\hline$\cdot * 1$ & $\cdot * 1 \cdot 1$ & 1 & -0.154 & -0.154 & 0.8344 & 0.361 \\
\hline.$* *|\cdot|$ & .***.$\quad 1$ & 2 & -0.220 & -0.249 & 2.5840 & 0.275 \\
\hline$\cdot 1 \cdot 1$ & $\cdot * 1 \cdot 1$ & 3 & 0.021 & -0.066 & 2.5999 & 0.458 \\
\hline$\cdot * 1 \cdot 1$ & .**1. & 4 & -0.151 & -0.235 & 3.4893 & 0.480 \\
\hline .*1 & .*** | | & 5 & -0.098 & -0.217 & 3.8789 & 0.567 \\
\hline$\cdot 1 \cdot 1$ & ***1 .1 & 6 & -0.017 & -0.231 & 3.8916 & 0.691 \\
\hline$\left.\cdot\right|^{*} \cdot \mid$ & .*1. & 7 & 0.120 & -0.066 & 4.5135 & 0.719 \\
\hline$\cdot|* * \cdot|$ & $\left.\cdot\right|^{*} \cdot \mid$ & 8 & 0.252 & 0.185 & 7.3819 & 0.496 \\
\hline.$* * 1 \cdot 1$ & $\cdot * 1 \cdot 1$ & 9 & -0.208 & -0.163 & 9.4370 & 0.398 \\
\hline$\left.\cdot\right|^{*} \cdot \mid$ & $\left.\cdot\right|^{*} \cdot \mid$ & 10 & 0.084 & 0.115 & 9.7876 & 0.459 \\
\hline$\cdot|\cdot|$ & $\cdot|\cdot|$ & 11 & -0.009 & -0.023 & 9.7919 & 0.549 \\
\hline.$* * 1 \cdot 1$ &.$* 1.1$ & 12 & -0.275 & -0.181 & 13.894 & 0.308 \\
\hline
\end{tabular}

*Probabilities may not be valid for this equation specification.

\section{Heteroscedasticity test}

Heteroscedasticity Test: Breusch-Pagan-Godfrey

\begin{tabular}{|c|c|c|c|}
\hline $\begin{array}{l}\text { F-statistic } \\
\text { Obs*R-squared } \\
\text { Scaled explained SS }\end{array}$ & $\begin{array}{l}0.641825 \\
\mathbf{6 . 0 7 3 6 8 8} \\
2.367801\end{array}$ & $\begin{array}{l}\text { Prob. F(8,16) } \\
\text { Prob. Chi-Square(8) } \\
\text { Prob. Chi-Square( } 8)\end{array}$ & $\begin{array}{l}0.7325 \\
\mathbf{0 . 6 3 9 0} \\
0.9676\end{array}$ \\
\hline \multicolumn{4}{|c|}{ Heteroscedasticity Test: ARCH } \\
\hline $\begin{array}{l}\text { F-statistic } \\
\text { Obs*R-squared }\end{array}$ & $\begin{array}{l}0.076393 \\
\mathbf{0 . 0 8 3 0 5 0}\end{array}$ & $\begin{array}{l}\text { Prob. F(1,22) } \\
\text { Prob. Chi-Square(1) }\end{array}$ & $\begin{array}{l}0.7848 \\
\mathbf{0 . 7 7 3 2}\end{array}$ \\
\hline \multicolumn{4}{|c|}{ Heteroscedasticity Test: White } \\
\hline $\begin{array}{l}\text { F-statistic } \\
\text { Obs*R-squared } \\
\text { Scaled explained SS }\end{array}$ & $\begin{array}{l}1.395352 \\
\mathbf{1 0 . 2 7 3 9 9} \\
4.005269\end{array}$ & $\begin{array}{l}\text { Prob. F(8,16) } \\
\text { Prob. Chi-Square(8) } \\
\text { Prob. Chi-Square( } 8)\end{array}$ & $\begin{array}{l}0.2710 \\
\mathbf{0 . 2 4 6 3} \\
0.8566\end{array}$ \\
\hline
\end{tabular}




\section{Stability test}
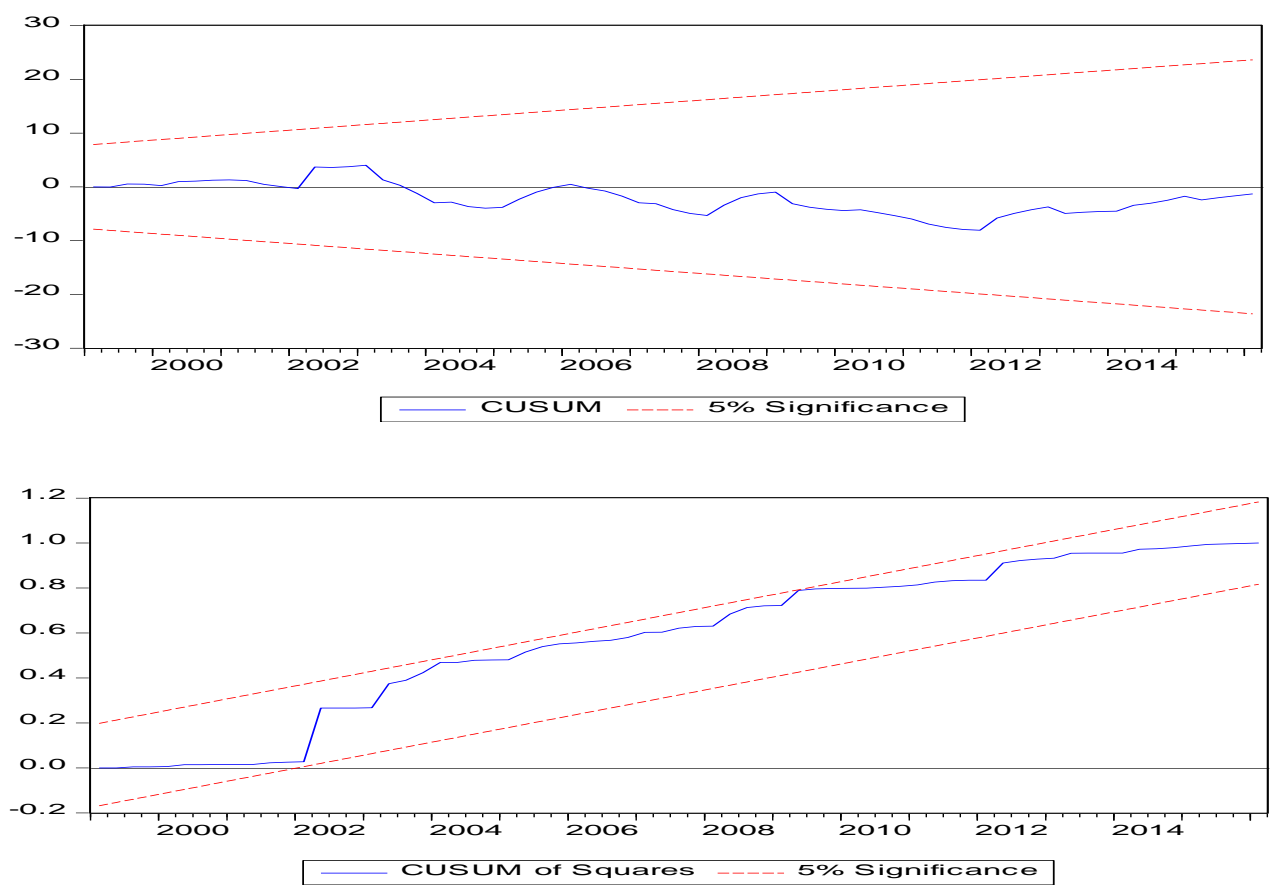

\section{Copyrights}

Copyright for this article is retained by the author(s), with first publication rights granted to the journal.

This is an open-access article distributed under the terms and conditions of the Creative Commons Attribution license which permits unrestricted use, distribution, and reproduction in any medium, provided the original work is properly cited. 